\title{
LIMITATIF KEWENANGAN JAKSA PENUNTUT UMUM DALAM TINDAK PIDANA KORUPSI
}

\author{
Novi Mardihana Sari, Universitas Pendidikan Nasional Graduate School \\ Magister Hukum, e-mail: novimardihanasari@yahoo.com \\ I Nyoman Budiana, Universitas Pendidikan Nasional, email: \\ budiananyoman1961@gmail.com
}

doi: https://doi.org/10.24843/KS.2020.v08.i09.p03

\begin{abstract}
ABSTRAK
Tulisan ini bertujuan untuk mengetahui pengaturan kewenangan jaksa penuntut umum dalam tindak pidana korupsi, serta mengkaji dan menganalisis limitative kewenangan jaksa dalam tindak pidana korupsi, sudahkah mencerminkan adanya kepastian hukum, keadilan dan kemanfaatan sesuai dengan tujuan hukum di Indonesia. Metode yang digunakan dalam tulisan ini menggunakan metode penelitian hukum normatif dengan pendekatan undang-undang (Statute approach) dan pendekatan konseptual (Conceptual approach). Hasil penelitian menunjukkan bahwa dalam penanganan tindak pidana korupsi, Jaksa berwenang melakukan penyelidikan, penyidikan dan penuntutan. Hal-hal yang menjadi limitatif kewenangan jaksa penuntut umum dalam penanganan tindak pidana korupsi diatur dalam Kitab Undang-Undang Hukum Acara Pidana, Undang-Undang Nomor 16 Tahun 2004 tentang Kejaksaan Republik Indonesia, serta Undang-Undang Nomor 31 Tahun 1999 tentang Pemberantasan Tindak Pidana Korupsi.
\end{abstract}

Kata Kunci : Limitatif Kewenangan, Jaksa Penuntut Umum, Korupsi

\begin{abstract}
This paper aims to determine the regulation of the authority of the public prosecutor in criminal acts of corruption, and to study and analyze the limitative authority of prosecoturs in criminal acts of corruption, has it reflected the existence of legal certainty, justice and usefulness in accordance with the legal objectives in Indonesia. The method used in this paper uses the normative legal research method with the statute approach and conceptual approach. The results showed that in handling corruption, the prosecutor has the authority to conduct investigations, investigations and prosecutions. Matters which become the limitative authority of public prosecutors in handling corruption are regulated inKitab Undang-Undang Hukum Acara Pidana, Undang-Undang Nomor 16 tahun 2004 concerning the attorney general of the republic of Indonesia, Undang-Undang Nomor 31 Tahun 1999 concerning eradication of criminal acts.
\end{abstract}

Keywords: limitative authority, Prosecutors, Corruption

\section{Pendahuluan}

\subsection{Latar Belakang Masalah}

Indonesia merupakan negara hukum, dimana ditegaskan didalam pasal 1 ayat (3) UUD 1945. Aturan ini bermakna bahwa di dalam negara kesatuan Republik Indonesia, hukum merupakan urat nadi seluruh aspek kehidupan masyarakat. Untuk mewujudkan prinsip-prinsip negara hukum, diperlukan baik norma hukum ataupun peraturan perundang-undangan, serta penegak hukum yang bersifat professional, 
berintegritas tinggi dan disiplin yang didukung oleh sarana dan prasarana hukus serta perilaku hukum. ${ }^{1}$ Korupsi dikatakan sebagai extraordinary crime sehingga dalam penangannya juga memerlukan penanganan khusus. Hukum dan penegak hukum, merupakan sebagian faktor penegakan hukum yang tidak bias diabaikan, karena jika diabaikan akan menyebabkan tidak tercapainya penegak hukum yang diharapkan. ${ }^{2}$

Kejaksaan sebagai salah satu penegak hukum di Indonesia, mempunyai kedudukan yang sentral dan peranannya yang strategis di dalam suatu negara hukum. Institusi kejaksaan sebagai filter dan dominus litis, karena hanya institusi kejaksaan yang dapat menentukkan apakah suatu perkara dapat diajukan ke Pengadilan atau tidaknya berdasarkan alat bukti yang sah. Sehingga keberadaannya membawa peran penting dalam sistem peradilan di Indonesia. Sebagai penyandang Dominus Litis (Procureur die de prcesvoering vaststelt), Kejaksaan juga merupakan satu-satunya instansi pelaksana putusan pidana (executive ambenaar).

Kejaksaan sebagai salah satu lembaga penegak hukum memiliki kewenangan dalam pemberantasan tindak pidana korupsi. Pasal 2 ayat (1) Undang-Undang Republik Indonesia Nomor 16 Tahun 2004 Tentang Kejaksaan Republik Indonesia merupakan lembaga pemerintah yang melaksanakan kekuasaan negara di bidang penuntutan serta kewenangan lain berdasarkan undang-undang. Pasal ini memberikan kewenangan kepada Kejaksaan RI tidak hanya berwenang melakukan penuntutan terhadap tindak pidana korupsi namun juga terdapat beberapa kewenangan lainnya yang berfungsi dalam upaya pemberantasan tindak pidana korupsi.

Jaksa juga yang memiliki kewenangan untuk melakukan penyidikan terhadap tindak pidana sesuai dengan undang-undang yang menjadi dasar hukumnya. Khususnya tindak pidana korupsi yang terjadi diberbagai kesenjangan dunia termasuk di Indonesia, sehingga diperlukan lembaga kejaksaan untuk dapat menangani tindak pidana korupsi sesuai undang-undang serta aturan-aturan yang berlaku di Indonesia.

Dalam beberapa artikel yakni artikel yang ditulis oleh I Made Agus Mahendra Iswara dan Ketut Adi Wirawan berjudul "Peran Kejaksaan dalam Pemberantasan Tindak Pidana Korupsi Desa di Indonesia" 3 dan artikel yang ditulis oleh : Lintang Tesalonika Natalia Luntungan yang berjudul "Kewenangan Jaksa Dalam Penyidikan Tindak Pidana Korupsi" 4 terdapat perbedaan pembahasan dengan tulisan ini. Tulisan ini lebih fokus dalam mengkaji mengenai limitatif kewenangan jaksa penuntut umum dalam penanganan tindak pidana korupsi.

\subsection{Rumusan Masalah}

Berdasarkan uraian latar belakang diatas, dapat dikemukakan rumusan masalah sebagai berikut:

1. Bagaimanakah pengaturan kewenangan jaksa penuntut umum dalam tindak pidana korupsi?

1 Effendy, Marwan, Kejaksaan RI, posisi dan Fungsinya dari perspektif Hukum, (Jakarta, PT. Gramedia Pustaka Utama, 2005), 2.

2 Soekanto Soerjono, Faktor-faktor yang mempengaruhi Penegakkan Hukum, (Jakarta, Rajawali, 1983), 5

3 Iswara, I. Made Agus Mahendra, and Ketut Adi Wirawan. "Peran Kejaksaan dalam Pemberantasan Tindak Pidana Korupsi Desa di Indonesia." KERTHA WICAKSANA: Sarana Komunikasi Dosen dan Mahasiswa 14, no. 1 (2020): 69-76.

4 Luntungan, Lintang Tesalonika Natalia. "Kewenangan Jaksa dalam Penyidikan Tindak Pidana Korupsi." Lex Crimen 2, no. 2 (2013), 194-203 
2. Bagaimanakah limitatif formalitas kewenangan jaksa penuntut umum dalam tindak pidana korupsi

\subsection{Tujuan Penulisan}

Adapun tujuan penelitian yang ingin dicapai adalah untuk mengetahui pengaturan kewenangan jaksa penuntut umum dalam tindak pidana korupsi serta mengkaji dan menganalisis limitatif kewenangan jaksa penuntut umum dalam tindak pidana korupsi.

\section{Metode Penelitian}

Jenis penelitian ini menggunakan jenis penelitian yuridis normatif, atau penelitian kepustakaan yang berkaitan dengan substansi hukum yang bersifat normative, dimana penelitian hukum normatif adalah suatu prosedur penelitian ilmiah untuk menemukan kebenaran berdasarkan logika keilmuan dipandang dari sisi normatif. Adapun tujuan dilakukannya penelitian ini adalah untuk mengkaji dan menganalisis tentang permasalahan terkait limitatif kewenangan jaksa dalam tindak pidana korupsi, apa sudah mencerminkan adanya kepastian hukum, keadilan dan kemanfaatan sesuai dengan tujuan hukum. Jenis pendekatan yang digunakan adalah pendekatan perundang-undangan (statue approach), yaitu pendekatan yang dilakukan dengan cara mempelajari peraturan-peraturan perundang-undangan yang berkaitan dengan penelitian ini seperti, Undang-Undang Dasar 1945 (UUD 1945), UndangUndang Nomor 16 Tahun 2004 tentang Kejaksaan Republik Indonesia (UU Kejaksaan RI), dan Undang-Undang Nomor 31 Tahun 1999 tentang Pemberantasan Tindak Pidana Korupsi (UU TIPIKOR). Pendekatan konsep hukum (conceptual approach), yaitu pendekatan tersebut dapat dicari pembenaran atas suatu teori atau asas yang digunakan dalam penelitian ini.

Untuk membahas permasalahan yang diajukan dalam penelitian ini digunakan bahan-bahan hukum, baik yang berupa bahan hukum primer maupun bahan hukum sekunder. Bahan hukum primer yang digunakan meliputi UUD 1945, KUHAP, UU No. 16 Tahun 2004 tentang Kejaksaan RI, UU TIPIKOR. Bahan hukum sekunder meliputi literatur-literatur hukum yang relevan dengan isu hukum yang dibahas. Di samping itu, untuk menunjang penulisan ini digunakan juga bahan-bahan nonhukum, seperti jurnal hukum dan berita online.

Pengumpulan bahan-bahan penelitian di atas dilakukan melalui penelusuran literatur di perpustakaan dan internet dengan teknik pencatatan yang meniru model kerja sistem kartu (card system). Bahan-bahan penelitian yang telah terkumpul selanjutnya diolah dan dianalisis secara kualitatif dengan teknik-teknik interpretatif dan argumentasi hukum, seperti konstruksi hukum dan penafsiran hukum. Selanjutnya, keseluruhan hasil penelitian disajikan secara deskriptif dalam bentuk uraian naratif.

\section{Hasil Dan Pembahasan}

\subsection{Pengaturan Kewenangan Jaksa Penuntut Umum dalam Tindak Pidana Korupsi.}

Kewenangan jaksa penuntun umum dalam menangani tindak pidana korupsi diatur dalam Kitab Undang-Undang Hukum Pidana (KUHAP) dan UU Kejaksaan RI. Setelah berlakunya KUHAP terdapat pembagian tahapan tugas kejaksaan yakni tahap pra-penuntutan dan tahap penuntutan. Tetapi KUHAP sendiri memuat kedua tahapan ini dalam Bab Penuntutan yakni pada Bab XV. Sejak berlakunya KUHAP, mkan pada 
dasarnya tugas jaksa hanya Sebagi penuntut umum dan mengeksekusi putusan pengadilan. Pasal 284 ayat (2) dalam aturan peralihan, menyebutkan bahwa :

"Dalam waktu dua tahun setelah undang-undang ini diundangkan, maka terhadap semua perkara diberlakukan ketentuatn undang-undang ini dengan pengecualian untuk sementara mengenai ketentuan khusus acara pidana sebagaimana tersebut pada undang-undang tertentu, sampai ada perubahan dana atau dinyatakan tidak berlaku lagi".

Selanjutnya dalam penjelasan pasal 284 (2) disebutkan bahwa yang dimaksud dengan ketentuan khusus acara pidana sebagaimana tersebut pada undang-undang tertentu ialah ketentuan khusus acara pidana sebagaimana tersebut pada antara lain undang-undang nomor 7 Drt. Tahun 1955 tentang pengusutan, penuntutan dan peradilan tindak pidana ekonomi, dan undang-undang nomor 3 tahun 1971 tentang pemberantasan tindak pidana korupsi. Ketentuan peralihan tersebut akan berlaku dengan catatan bahwa semua ketentuan khusus acara pidana sebagaimana tersebut pada undang-undang tertentu akan ditinjau kembali, diubah atau dicabut dalam waktu yang sesingkat-singkatnya. KUHAP pasal 284 ayat (2) inilah yang menjadi acuan kewenangan kejaksaan melakukan penyidikan terhadap tindak pidana korupsi. Ditegaskan kembali dalam ketentuan pasal 284 ayat (2) KUHAP terdapat pembatasan dengan adanya redaksi "sementara". Terkait diksi "sementara" terdapat beberapa pendapat dalam mengartikan kewenangan tersebut.

Menurut OC. Kaligis kewenangan jaksa sebagai penyidik tindak pidana tertentu hanya dipertahankan dalam waktu 2 (dua) tahun atau sampai ada pergantian undangundang khusus seperti undang-undang tentang tindak pidana korupsi dan tindak pidana ekonomi, yang artinya kewenangan jaksa melakukan penyidikan terhadap tindak pidana khusus sudah habis masa berlakunya. Kewenangan tersebut diberikan hanya sampai undang-undang terkait dengan tindak pidana khusus diperbaharui dan posisi kejaksaan dikembalikan sebagai pengawas sesuai dengan sistem yang diatur dalam KUHAP. ${ }^{5}$ Asas lex certa menyatakan bahwa setiap peraturan hukum harus dapat diartikan secara tegas. Hal tersebut menegaskan kewenangan penyidikan itu tetap berlau bagi jaksa untuk tindak pidana korupsi, dan tindak pidana ekonomi.

Berlakunya UU Kejaksaan RI dalam pasal 30 ayat (1) huruf d menyebutkan "tugas dan kewenangan jaksa adalah melakukan penyidikan terhadap tindak pidana tertentu berdasarkan undang-undang". Kewenangan jaksa tersebut menuai perdebatan dalam hal melakukan penyidikan terhadap tindak pidana korupsi. Penjelasan pasal tersebut, yang dimaksud dengan pidana tertentu berdasarkan undang-undang adalah sebagaimana diatur dalam undang-undang nomor 31 tahun 1999 tentang pemberantasan tindak pidana korupsi sebagaimana telah diubah dengan undang-undang nomor 20 tahun 2001, Jo undang-undang nomor 30 tahun 2002 tentang komisi pemberantasan tindak pidana korupsi dan undang-undang-undang nomor 26 tahun 2000 tentang hak asasi manusia.

Pendelegasian kewenangan tersebut dijelaskan dalam latar belakangan UU Kejaksaan yaitu untuk menampung beberapa ketentuan perundang-undangan yang sebelumnya telah memberikan kewenangan kepada kejaksaan untuk melakukan penyidikan. Berdasarkan penjelasan pasal tersebut maka dapat dikatakan bahwa kejaksaan mempunyai hak privilege yakni hak khusus untuk dapat melakukan

5 O.C. Kaligis, Pengawasan Terhadap Jaksa Selaku Penyidik Tindak Pidana Korupsi, (Bandung,, PT. Alumni, 2006), 225. 
tindakan penyidikan terhadap tindak pidana korupsi. ${ }^{6}$ Pasal 30 ayat (1) huruf d UU Kejaksaan RI, pada tahun 2007 dilakukan uji materiil. Pengujian materiil, pemohon menguraikan telah terjadinya disharmonisasi hukum tentang kedudukan dan kewenangan jaksa sebagai penyidik atau penuntut umum. Dualisme kewenangan yang dimiliki kejaksaan rawan menimbulkan abuse of power. ${ }^{7}$

Oemar Seno Adji mengatakan bahwa kejaksaan merupakan pihak yang bertanggung jawab terhadap proses dari awal, sampai di hadapan peradilan diberikan kewenangan yang sama, karena kejaksaan yang melakukan pengawasan terhadap penyidikan dan penyelidikan. ${ }^{8}$ Pernyataan tersebut menegaskan bahwa intergrated criminal justice sistem merupakan sistem yang memandang proses penyelesaian perkara pidana sebagai satu rangkaian kesatuan sejak penyidikan, penuntutan, memutuskan perkara, hingga penyelesaian di tingkat lembaga permasyarakatan. Jadi, bukan sistem yang menjurus pada pembagian fungsi yang dapat mengakibatkan sulit dan lambatnya penyelesaian masalah yang ada.

\subsection{Bentuk Limitatif pengaturan Kewenangan Jaksa Penuntut Umum (ius constituendum) Dalam Tindak Pidana Korupsi Guna Mencegah Terjadinya Disparitas Penuntutan}

Jaksa penuntut umum dalam penanganan tindak pidana korupsi berwenang melakukan penyelidikan, penyidikan serta penuntutan yang diatur dalam pasal 30 ayat (1) UU Kejaksaan RI. ${ }^{9}$ Tugas dan fungsi jaksa penuntut umum sebagai penyelidik, mempunyai wewenang mengadakan tindakan lain menurut hukum yang bertanggung jawab (pasal 5 angka 4 KUHAP). Makna "tindakan lain" tersebut adalah tindakan dari penyelidik untuk kepentingan penyelidikan dengan syarat:

1. Tidak bertentangan dengan suatu aturan hukum

2. Selaras dengan kewajiban hukum yang mengharuskan dilakukannya tindakan jabatan

3. Tindakan itu harus patut dan masuk akal dan termasuk dalam lingkungan jabatannya

4. Atas pertimbangan yang layak berdasarkan keadanaan memaksa

5. Menghormati hak asasi manusia.

Fungsi jaksa penuntut umum sebagai penyidik juga diatur dalam pasal 7 dan pasal 8 KUHAP. Wewenang jaksa penuntut umum dalam pasal 14 huruf I KUHAP menyatakan:" Mengadakan tindakan lain dalam tugas dan tanggung jawab sebagai penuntut umum menurut undang-undang ini". Makna "tindakan lain" dalam pasal tersebut adalah meneliti identitas tersangka, barang bukti, antara penyidik, penuntut umum dan pengadilan. ${ }^{10}$

Selain tugas dan fungsi yang sudah diuraikan diatas, jaksa penuntut umum juga mempunyai wewenang untuk melakukan penyadapan (wiretapping) yang diatur dalam

6 Ardiansyah, Irfan. Op.Cit, 76.

7 MD, Moh. "Mahfud, Penegakan Hukum Dan Tata Kelola Pemerintahan Yang Baik, Bahan pada Acara Seminar Nasional "Saatnya Hati Nurani Bicara" yang diselenggarakan oleh DPP Partai HANURA." Mahkamah Konstitusi Jakarta 8 Januari 2009.

8 Putusan Mahkamah Konstitusi Nomor 28/PUU-V/2007, 90.

9 Akfini Aditias, "Analisis Hukum Tentang Disparitas Pidana Dalam kasus Tindak Pidana Korupsi Penyalahgunaan Wewenang Proyek Pengerjaan Jalan (Pada kasus Putusan Nomor 54/Pid.Sus/Tipikor/2013/PN.PBR)", JOM Fakultas Hukum, Vol. II No. 2, Oktober, 2015.

10 Eddy Rifai, Penegakkan Hukum Tindak Pidana Korupsi, (Bandar lampung, Justice Publisher, 2014). 
pasal 26 undang-undang nomor 20 tahun 2001 tentang pemberantasan tindak pidana korupsi (selanjutnya disebut dengan UU Pemberantasan TIPIKOR). Ketentuan ini dimaksud untuk mempercepat proses penyidik yang pada dasarnya di dalam KUHAP untuk membuka, memeriksa atau menyita surat hars memperoleh izin terlebih dahulu dari Ketua Pengadilan Negeri (pasal 30 UU Pemberantasan TIPIKOR).

Secara yuridis, kewenangan jaksa penuntut umum dalam tindak pidana korupsi sudah diuraikan dalam sub bab diatas, secara teoritis indikator yang mendasari kewenangan jaksa penuntut umum untuk melakukan penyidikan tindak pidana korupsi sebagai berikut:

1. Alasan Filosofis

Kewenangan Jaksa melakukan penyidikan dan sekaligus penuntutan, akan menghapus mata rantai pra penuntutan yang telah menyebabkan terjadinya bolak-balik perkara antara penuntut umum dengan penyidik. Dengan adanya kewenangan Jaksa melakukan penyidikan maka dapat dihindarkan bolak-balik perkara, sehingga proses penyelesaian perkara menjadi efisien dan efektif. 11

2. Alasan Sosiologis

Kejahatan korupsi adalah kejahatan kerah putih (white collar crime) dengan karakteristik pelaku memiliki intelektual tinggi, sangat rapi menyembunyikan bukti dan pelaksanaannya lebih terorganisir. Oleh karena itu, pengungkapan perkara tindak pidana korupsi tidak mudah karena terkait dengan dimensi waktu yaitu terbongkar setelah terjadi sekian lama. Sehingga barang bukti sering banyak yang hilang. Dalam hubungan itu pengalaman dan kemampuan Kejaksaan menyidik perkara tindak pidana korupsi sudah diakui oleh masyarakat ${ }^{12}$

3. Alasan Historis

Kejaksaan telah melakukan penyidikan tindak pidana korupsi sejak masa berlakunya Het Herziene Inlandsch Reglemen (HIR) sampai dengn saat ini.

4. Alasan Praktis

Kewenangan Jaksa melakukan penyidikan secara praktis akan mempercepat Jaksa menguasai kasus serta pembuktiannya sehingga penyelesaian perkara tindak pidana korupsi akan lebih efektif dan efisien. Penguasaan kasus dan pemahaman pembuktian oleh Jaksa secara awal akan memudahkan Jaksa menyusun surat dakwaan serta mengantisipasi kemungkinan-kemungkinan yang akan terjadi selama persidangan. ${ }^{13}$

\section{Kesimpulan}

Limitatif kewenangan jaksa penuntut umum dalam penanganan tindak pidana korupsi yaitu berwenang melakukan penyelidikan, penyidikan serta penuntutan (pasal 30 ayat 1 UU Kejaksaan RI). Tugas dan fungsi jaksa sebagai penyelidik mempunyai wewenang mengadakan tindakan lain seperti meneliti identitas tersangka, barang bukti antara penyidik, penuntut umum dan pengadilan yang diatur dalam

11 Saripi, Mohammad Ridwan. "Jaksa Selaku Penyidik Tindak Pidana Korupsi." Jurnal Hukum UNSRAT 22, no. 7 (2016), 20-32.

12 Ginting, Jamin. "Faktor Hukum dan Non Hukum Dalam Putusan Tindak Pidana Korupsi di Indonesia." Media Hukum 19, no. 2 (2012). 308-323.

13 Guse Prayudi, Tindak Pidana Korupsi, Dipandang Dalam Berbagai Aspek, (Yogyakarta, Pustaka Pena, 2010), 156. 
Pasal 4, 5, 7, 8 dan 14 KUHAP. Limitatif terakhir jaksa penuntut umum dalam penanganan tindak pidana korupsi diatur dalam pasal 26 dan 30 UU Pemberantasan TIPIKOR, yang mempunyai wewenang untuk melakukan penyadapan, membuka memeriksa atau menyita surat-surat terkait dengan tindak pidana korupsi yang sebelumnya harus mendapatkan izin dari Ketua Pengadilan Negeri. Selanjutnya bagian akhir adalah memberikan rekomendasi kepada Pemerintah, Hendaknya dilakukan restrukturisasi undang-undang kejaksaan republik Indonesia yang menegaskan tentang limitatif kewenangan jaksa penuntut umum dalam penegakkan tindak pidana korupsi serta pendelegasian kewenangan terhadap jaksa dalam melakukan penyidikan terhadap tindak pidana korupsi, menghapus kewenangan penegak hukum lainnya (Polisi) melakukan penyidikan tindak pidana korupsi agar tidak terjadinya konflik kewenangan dalam penanganan tindak pidana korupsi.

\section{DAFTAR PUSTAKA}

\section{Buku}

Effendy, Marwan, Kejaksaan RI, posisi dan Fungsinya dari perspektif Hukum, (Jakarta, PT. Gramedia Pustaka Utama, 2005).

Indonesia, Himpunan Tata Naskah dan Petunjuk Teknis Penyelesaian Perkara Tindak Pidana Khusus 2002-2005, Buku I-III, Jaksa Agung Muda Tindak Pidana Khusus, (Jakarta, Kejaksaan Agung RI, 2002).

Kaligis, O.C., Pengawasan Terhadap Jaksa Selaku Penyidik Tindak Pidana Korupsi, (Bandung,, PT. Alumni, 2006).

Prayudi, Guse, Tindak Pidana Korupsi, Dipandang Dalam Berbagai Aspek, (Yogyakarta, Pustaka Pena, 2010).

Soekanto, Soerjono, Faktor-faktor yang mempengaruhi Penegakkan Hukum, (Jakarta, Rajawali, 1983).

\section{Jurnal Ilmiah}

Adhyaksa Triwuladari, "Disparitas Penuntutan Perkara Tindak Pidana Korupsi di Wilayah Hukum Kejaksaan Tinggi Riau", JOM Fakultas Hukum, Volume 1, Nomor 2 (2014).

Akfini Aditias, “Analisis Hukum Tentang Disparitas Pidana Dalam kasus Tindak Pidana Korupsi Penyalahgunaan Wewenang Proyek Pengerjaan Jalan (Pada kasus Putusan Nomor 54/Pid.Sus/Tipikor/2013/PN.PBR)", JOM Fakultas Hukum, Vol. II No. 2, (2015).

Ardiansyah, Irfan. "Pengaruh Disparitas Pemidanaan Terhadap Penanggulangan Tindak Pidana Korupsi di Indonesia." Jurnal Hukum Respublica 17, no. 1 (2017): 76101.

Eddy Rifai, "Penegakkan Hukum Tindak Pidana Korupsi”, Justice Publisher, Bandar lampung (2014).

Hany, Nicolas. "Disparitas Pidana dalam Putusan Pengadilan Tindak Pidana Korupsi Semarang." Jurnal Skripsi, Program Studi Ilmu Hukum Universitas Atmajaya Yogyakarta, Yogyakarta (2015).

Iswara, I. Made Agus Mahendra, and Ketut Adi Wirawan. "Peran Kejaksaan dalam Pemberantasan Tindak Pidana Korupsi Desa di Indonesia." KERTHA WICAKSANA: Sarana Komunikasi Dosen dan Mahasiswa 14, no. 1 (2020): 69-76. 
Luntungan, Lintang Tesalonika Natalia. "Kewenangan Jaksa dalam Penyidikan Tindak Pidana Korupsi." Lex Crimen 2, no. 2 (2013), 194-203

MD, Moh. "Mahfud, Penegakan Hukum Dan Tata Kelola Pemerintahan Yang Baik, Bahan pada Acara Seminar Nasional "Saatnya Hati Nurani Bicara" yang diselenggarakan oleh DPP Partai HANURA." Mahkamah Konstitusi Jakarta 8 Januari 2009.

Ginting, Jamin. "Faktor Hukum dan Non Hukum Dalam Putusan Tindak Pidana Korupsi di Indonesia." Media Hukum 19, no. 2 (2012). 308-323.

Riskanawati, Riskanawati, Oheo K. Haris, and Handrawan Handrawan. "Disparitas Tindak Pidana Korupsi (Pada Putusan Nomor 14/PID. SUS/TPK/2016/PN. KDI dan Nomor 20/PID. SUS/TPK/2016/PN. KDI)." Halu Oleo Legal Research 1, no. 1 (2019): 36-44.

Saripi, Mohammad Ridwan. "Jaksa Selaku Penyidik Tindak Pidana Korupsi." Jurnal Hukum UNSRAT 22, no. 7 (2016), 20-32.

Spohn Cassia C, "How do judge decide: The search for fairness and justice in punishment" Sage Publication, Washington (2008).

\section{Peraturan Perundang-Undangan}

Undang-Undang Dasar Negara Republik Indonesia Tahun 1945

Undang-Undang Nomor 16 Tahun 2004 Tentang Kejaksaan Republik Indonesia

Kitab Undang-Undang Hukum Acara Pidana

Undang-Undang Nomor 31 Tahun 1999 tentang Pemberantasan Tindak Pidana Korupsi

Putusan Mahkamah Konstitusi Nomor 28/PUU-V/2007. 